\author{
Beata Meyer \\ Uniwersytet Szczeciński \\ Wydział Zarządzania i Ekonomiki Usług \\ Katedra Marketingu Usług \\ beata.meyer@wzieu.pl \\ Agnieszka Niezgoda \\ Uniwersytet Ekonomiczny w Poznaniu \\ Wydział Gospodarki Międzynarodowej \\ Katedra Turystyki \\ agnieszka.niezgoda@ue.poznan.pl
}

\title{
POSTRZEGANIE CZASU WOLNEGO A KSZTAŁTOWANIE PRZESTRZENI REKREACJI I PRZESTRZENI TURYSTYCZNEJ NA OBSZARZE MIEJSKIM
}

\begin{abstract}
Abstrakt: Celem autorek artykułu jest próba identyfikacji relacji pomiędzy zmianami w postrzeganiu czasu wolnego a kreowaniem przestrzeni rekreacji i przestrzeni turystycznej na obszarach miejskich. Autorki w szczególności śledzą zmiany związane z tzw. trzecią falą (TOFFLER 2001), kompresją czasu (NIEZGODA 2017) oraz odejściem od tzw. synchronizacji. Ilustracją prowadzonych wcześniej rozważań jest analiza aktywności rekreacyjnej mieszkańców i turystów w Szczecinie oraz próba identyfikacji relacji przestrzeni rekreacji i przestrzeni turystycznej. Wraz z postępującą kompresją czasu wolnego aktywność turystów w odwiedzanych obszarach staje się podobna do form aktywności wolnoczasowej mieszkańców, co powoduje jej realizację w tym samym otoczeniu. W przestrzeni miasta postępuje interferencja przestrzeni rekreacji i przestrzeni turystycznej, uniemożliwiająca ich rozdzielenie, ale nadal pozwalająca na wyodrębnienie pewnych podprzestrzeni, o wyższej intensywności zachowań turystycznych lub rekreacyjnych.
\end{abstract}

Słowa kluczowe: czas wolny, przestrzeń turystyczna, przestrzeń rekreacji.

\section{WPROWADZENIE}

Istnienie czasu wolnego uważa się za niezbędny warunek uczestnictwa w rekreacji i ruchu turystycznym. Wpływ czasu wolnego na uczestnictwo w turystyce i rekreacji można jednak analizować szerzej. Wynika to $\mathrm{z}$ faktu zmieniającej się struktury czasu i jego podziałów, odejścia od tzw. synchronizacji, czyli zacierania różnic pomiędzy czasem pracy a czasem wolnym (TOFFLER 2001), oraz tzw. kompresji czasu (CZAJA 2011, GoŁEMBSKI, NiEZGODA 2012, 2017). Udział w rekreacji staje się jednak zjawiskiem coraz powszechniejszym, co jest związane również z pojawianiem się nowych form rekreacji i przestrzeni z nimi związanych. Różnorodność możliwości spędzania czasu i dostępność urozmaiconej oferty prowadzą do nakładania się w coraz większym stopniu przestrzeni rekreacji i turystyki.
Procesy te powodują, że zależność pomiędzy czasem wolnym a rekreacją należy analizować szerzej, a nie tylko uznawać czas wolny za tradycyjny podstawowy warunek uczestnictwa w formach rekreacji. Użyteczność czasu oraz jego cena dla osób biorących udział w różnych formach rekreacji i turystyki powodują, że dynamicznie zmienia się zasięg zarówno przestrzeni turystycznej, jak i rekreacji, a dodatkowo postępuje proces ich interferencji.

Celem autorek artykułu jest próba identyfikacji relacji pomiędzy zmianami w postrzeganiu czasu wolnego a kreowaniem przestrzeni rekreacji i przestrzeni turystycznej na obszarach miejskich.

Autorki w szczególności śledzą zmiany związane z tzw. trzecią falą (TOFFLER 2001), kompresją czasu oraz odejściem od tzw. synchronizacji. W artykule 
postawiono tezę, że procesy związane $\mathrm{z}$ interferencją przestrzeni turystycznej i rekreacji mogą wynikać z szerokich zmian związanych $\mathrm{z}$ rolą i oceną czasu wolnego we współczesnym społeczeństwie. Wybrane wątki rozważań teoretycznych zostały zilustrowane wynikami pilotażowych badań zachowań rekreacyjnych mieszkańców Szczecina i turystów odwiedzających miasto. Badania były częścią projektu pt. „Miasto jako obszar aktywności turystycznej i rekreacyjnej mieszkańców, na przykładzie Szczecina", realizowanego w latach 2012-2017 przez Zakład Gospodarki Turystycznej i Uzdrowiskowej w Katedrze Zarządzania Turystyką na Wydziale Zarządzania i Ekonomiki Usług Uniwersytetu Szczecińskiego. Badania przeprowadzono przy wykorzystaniu metody sondażu diagnostycznego, zastosowano losowy prosty dobór próby, badaniu poddano 390 mieszkańców (liczba mieszkańców Szczecina w okresie badawczym to 408172 osoby) oraz 248 turystów odwiedzających Szczecin (od czerwca do września 2015 r.).

\section{CZAS WOLNY - ISTOTA I DEFINICJA}

$\mathrm{Na}$ postrzeganie czasu, jego mierzenie oraz podziały na różne kategorie, w tym na czas pracy i czas wolny, wpłynęły przeobrażenia cywilizacyjne, a przede wszystkim rozwój gospodarki kapitalistycznej. Kapitalistyczny system pracy zmusił do wyraźnego podziału między czasem pracy a czasem wolnym. Nastąpiła zmiana oceny czasu wolnego, a T. Veblen uważał go za wyznacznik tzw. "klasy próżniaczej”, natomiast etyka purytańska klasyfikowała "trwonienie czasu jako występek" (WHITROW 2004, s. 239). W wyniku procesów społecznych w XIX w. pojawiły się prawne gwarancje czasu wolnego. Tradycja pewnych zachowań i rytuałów $\mathrm{z}$ nim związanych jest więc silnie zakorzeniona i osadzona $w$ świadomości społeczeństwa XXI w. (BomBOL 2008, s. 7).

Czas wolny jest najczęściej definiowany, w opozycji do czasu pracy, jako sfera przyjemności, dobrowolności i bezinteresowności (NIEZGODA 2014). Przyjęcie powyższego sposobu pojmowania czasu wolnego oznacza, że nie można skonstruować listy czynności, które ten czas zajmują (MYŚLIWSKA 2011, s. 136). Jak podaje S. CZAJA (2011, s. 229), relacje pomiędzy czasem pracy a czasem wolnym można ujmować w różny sposób. Niektórzy badacze uważają, że główną funkcją czasu wolnego jest przygotowanie do czasu pracy. Drugie podejście traktuje czas wolny jako wynagrodzenie za wyalienowaną pracę. Trzeci sposób, to pojmowanie czasu wolnego w kontekście przekształcania czasu pracy w „niepracę".

Wymienione ujęcia czasu wolnego powodują, że dopiero kombinacja tych wymiarów prowadzi do zdefiniowania czasu wolnego. Taką definicję proponuje M. BOMBOL (2005, s. 15): „czas wolny jest więc czasem jednostki, satysfakcjonująco spożytkowanym dzięki wolnym wyborom, wypełnionym czynnościami wynikającymi z wewnętrznie lub zewnętrznie relatywnie wolnych uwarunkowań. Jest więc czasem wolnym od jakichkolwiek ograniczeń". Jednak we współczesnym świecie zachodzi trudność w odróżnieniu działań całkowicie wolnych od przymusu. Zależności pomiędzy wolnością wyboru działań a chęcią ich podejmowania są skomplikowane.

\section{CZAS WOLNY JAKO WARUNEK REKREACJI}

Aktywność podejmowana dobrowolnie przez człowieka w czasie wolnym jest najczęściej określana mianem rekreacji. Dynamicznie postępujące zmiany w postrzeganiu znaczenia czasu wolnego i jego wykorzystania (nie tylko z punktu widzenia jednostki, ale także społeczeństwa i gospodarki) stały się implikacją dyskusji nad zależnościami (i definicjami) czasu wolnego i rekreacji, często w połączeniu z turystyką i sportem, m.in. R. KRAUS (1971), R. KRAUS, J.A. PETERSON, W.D. MARTIN (1985), A.J. VEAL (1992), J.T. HAWORTH (1997), L. MEERAS (2010), A.R. HuRD, D.M. ANDERSON (2011), D.R. Austin, Y. LeE (2013), A. Gulam (2016). Podobne debaty nad zakresem pojęciowym czasu wolnego, rekreacji i turystyki toczą się również w polskiej literaturze. Nadal jednak najczęściej przywoływana jest definicja T. Wolańskiej, która wskazuje, że „rekreacja obejmuje różnego rodzaju zajęcia, które podejmowane są $\mathrm{w}$ wolnym czasie, dobrowolnie, dla przyjemności, jak również kształtowania własnej osobowości, odnowy i pomnażania sił psychofizycznych" (WOLAŃSKA 1997, cyt. za: MEYER, red. 2015, s. 15). Podobnie uważa A. Kowalczyk, określając rekreację jako „wszelkie czynności podejmowane dobrowolnie dla regeneracji sił fizycznych i psychicznych, a przejawiające się w uczestniczeniu w rozrywkach kulturalnych, w grach i zajęciach sportowych, realizowanych w czasie wolnym od zajęć szkolnych, służbowych lub domowych" (KowALCZYK 2000). Zachowując główne atrybuty, S. Tanaś w sposób syntetyczny określa rekreację jako „każdą formę regeneracji sił człowieka, przejawiającą się spędzaniem czasu wolnego aktywnie lub biernie" (TANAŚ 2008). Wszechstronną definicję rekreacji uwzględniającą jej kluczowe aspekty sformułował A. Dąbrowski, uznając ją za „wszelkie akceptowane społecznie formy ludzkiej aktywności, majace miejsce $\mathrm{w}$ czasie wolnym, podejmowane dobrowolnie, bezinteresownie i dla przyjemności, służące odnowie i umacnianiu sił człowieka, jego inne od codziennej, aktywnej i różnorodnej samorealizacji 
o cechach zabawy, realizowanej indywidualnie, w grupach lub występującej jako zjawisko globalne" (DĄBROWSKI 2006).

Formy wybieranej aktywności zależą od wielu czynników, takich jak: wiek, pozycja społeczna i materialna jednostki, wykształcenie czy miejsce zamieszkania. Sposób spędzania czasu wolnego jest silnie warunkowany społecznym, cywilizacyjnym i ekonomicznym otoczeniem jednostki (BombOL 2005, s. 15, BellezZa, PAHARIA, KeINAN 2017). Poprzez zachowania $\mathrm{w}$ czasie wolnym ludzie chcą pokazać status społeczny czy przynależność do grupy. Analizując zmiany czasu wolnego, można określić zmiany w rekreacji i turystyce jako sektorach wypełniających go (NIEZGODA 2014, NIEZGODA 2017). D.G. ReID i in. (1993) dokonują próby ukazania zazębiania się kategorii czasu wolnego, rekreacji, turystyki i innych zajęć. Jednak według tych autorów zależności nie dają się jednolicie wyeksponować.

Przeobrażenia związane z czasem wolnym można analizować też $\mathrm{w}$ związku $\mathrm{z}$ procesami charakteryzującymi przemiany cywilizacyjne. Należą do nich: konsumpcja na pokaz (BELLEZZA, PAHARIA, KEINAN 2017), indywidualizacja (ButLer 2006, ReICH, PECHLANER, HoElZL 2006, NiEZGODA 2017), kompresja czasu (CZAJA 2011, GoŁEMBSKI, NiEZGODA 2012, NiEZGODA 2017).

Konsumpcja na pokaz charakteryzuje społeczeństwa zamożne, w których zestaw nabywanych dóbr i usług może być odzwierciedleniem statusu majątkowego (i społecznego) konsumentów. Formy rekreacji, a w szczególności wyjazdy turystyczne mogą stać się synonimem luksusu.

Indywidualizacja charakteryzuje rynki, na których konsumenci mogą odnaleźć dobra i usługi odpowiadające ich jednostkowym, często niepowtarzalnym potrzebom. Przykładem rynku zaspokajającego zindywidualizowane potrzeby jest turystyka, gdzie konsument może komponować dowolny pakiet usług.

Czas wolny staje się dla jednostki cennym zasobem, ponieważ daje satysfakcję $\mathrm{i}$ jest oceniany poprzez dystans do czasu pracy. Jak stwierdza B. JUNG (2011, s. 169), w warunkach względnego dobrobytu konsumentów z państw OECD jedną z barier wzrostu konsumpcji w tych krajach jest nie tyle brak siły nabywczej, co brak czasu na niektóre formy spożycia. Prowadzi to do wyboru czasooszczędnych form aktywności przez konsumentów.

Ludzie, którzy więcej zarabiają, korzystają z mniejszej ilości czasu wolnego (NIEZGODA 2017). Czas ten staje się coraz cenniejszy, a ludzie chcą wykorzystać go jak najlepiej. Zauważalne staje się zjawisko „kompresji czasu i przestrzeni". Oznacza ono postępujące obniżanie rangi przestrzeni publicznej i niwelowanie odległości czasowych. Zjawisko to rozumiane jest jako zmiana atrybutów współczesnego życia, co wyraża się intensyfikacją produkcji i konsumpcji $\mathrm{w}$ jednostce czasu (CZAJA 2011, s. 227) Czas traci swój wymiar, komunikacja (najszerzej rozumiana) wymaga coraz mniej czasu. Przestrzeń przestaje się liczyć tak jak dawniej, odległości znaczą coraz mniej. Elity dzisiejszego świata, ale też turyści są coraz mniej związani z konkretnym terytorium, coraz bardziej niezależni od ograniczonych przestrzeni społeczno-kulturowych i politycznych, stają się w tym sensie eksterytorialni (GoŁEMBSKI, NIEZGODA 2012). Po stronie konsumenta kompresja czasu wyraża się $\mathrm{w}$ intensyfikacji produkcji i konsumpcji czy obu tych czynności naraz w jednostce czasu (NiEZGODA 2017).

Kolejnym zjawiskiem związanym z przemianami czasu wolnego jest odejście od tzw. synchronizacji jako rezultat tzw. trzeciej fali (TOFFLER 2001). Zjawisko to pozwala konsumentowi łączyć aktywność zawodową z czasem rekreacji i wypoczynku. Granice pomiędzy czasem wolnym a czasem pracy zaczynają się zacierać (KACHNIEWSKA i in. 2012 s. 144). Przykładem może być korzystanie przez turystę z usług rekreacyjnych hotelu podczas udziału w konferencji.

Z kolei praca przy komputerze, a nawet telefonie, powoduje, że trudno rozdzielić poszczególne czynności kwalifikowane jako praca i jako czas wolny (np. odbieranie wiadomości prywatnych i służbowych, przerwy $\mathrm{w}$ trakcie pisania na oglądanie wiadomości w Internecie).

W kontekście przemian czasu wolnego interesujące staje się kształtowanie i różnicowanie przestrzeni rekreacji oraz jej relacje z przestrzenią turystyczną. Przestrzeń rekreacji (w odróżnieniu od przestrzeni turystycznej, która jest szeroko definiowana, klasyfikowana i kategoryzowana, m.in. S. LISZEWSKI 1995, 2013, B. WŁoDARCZYK 2014, A. KoWALCZYK 2014, M. WIĘCKOWSKI 2014) nie została dotychczas zdefiniowana w sposób jednoznaczny, ani też poddana szczegółowej systematyzacji. Najczęściej przywoływana jest definicja sformułowana przez M. Drzewieckiego, określająca przestrzeń rekreacyjną jako „część przestrzeni geograficznej, posiadającą cechy korzystne (umożliwiające i sprzyjające) do realizacji różnych form wypoczynku charakteryzujące się istnieniem procesów rekreacyjnych o rozmiarach istotnych społecznie i przestrzennie" (DRZEWIECKI 1992, s. 13). Według S. TOCZEK-WERNER (2007) w przestrzeni (rekreacyjnej), w której realizowana jest aktywność rekreacyjna, można wyróżnić ośrodki aktywności rekreacyjnej, ukierunkowane na zaspokajanie oczekiwań i potrzeb osób preferujących określone formy aktywności, (np. kluby fitness, pływalnie, studia tańca), oraz tereny, które umożliwiają rekreację i nie ograniczają jej form (np. parki, skwery, boiska, place zabaw).

Na potrzeby niniejszego opracowania przyjęto, że przestrzeń rekreacji to taka, w której realizowana jest aktywność rekreacyjna. Charakter miejsca pozwala na wyróżnienie przestrzeni otwartej (aktywność realizowana 
jest na wolnym powietrzu) i zamkniętej (aktywność realizowana jest w obiektach zamkniętych), dodatkowo w ich ramach można wydzielić przestrzenie, w których podejmowane są formy aktywności rekreacyjnej określonego typu (np. pływanie, taniec, spacery). Ponadto każdy z typów przestrzeni może reprezentować przestrzeń formalną (rodzaje aktywności zorganizowanej i/lub odpłatne) lub nieformalną (formy aktywności nieodpłatne, realizowane w sposób zindywidualizowany) ${ }^{1}$.

Przestrzeń rekreacji najczęściej jest postrzegana w kontekście aktywności podejmowanej przez mieszkańców danego obszaru w czasie wolnym. Jednak w przypadku obszarów atrakcyjnych turystycznie może nastąpić (i następuje) pewna interferencja przestrzeni rekreacji (wykorzystywanej przez mieszkańców w czasie wolnym) i przestrzeni turystycznej (wykorzystywanej przez turystów do realizacji aktywności turystycznej i rekreacyjnej). Wydaje się, że chociaż decyzje dotyczące aktywności w czasie wolnym podejmowane są rozłącznie przez mieszkańców i turystów, to wraz ze zmianami w postrzeganiu i konsumowaniu czasu wolnego wybierane formy aktywności coraz częściej są realizowane $\mathrm{w}$ tej samej przestrzeni i mają podobny charakter. Jest to wynik z jednej strony zmian w postawach i zachowaniach mieszkańców, którzy w czasie wolnym spędzanym w miejscu zamieszkania wykorzystują jego najbardziej atrakcyjne fragmenty, a także często łączą czas pracy z czasem wolnym $w$ jednej przestrzeni. $Z$ drugiej strony jest to efekt zmian w zachowaniu turystów, którzy chcą nie tylko aktywnie i w atrakcyjnym otoczeniu spędzać czas podczas wyjazdu, ale także poznać, jak żyją na co dzień mieszkańcy odwiedzanego obszaru (turystyka poza utartym szlakiem).

\section{AKTYWNOŚĆ REKREACYJNA MIESZKAŃCÓW I TURYSTÓW W SZCZECINIE}

Ilustracją prowadzonych wcześniej rozważań jest analiza aktywności rekreacyjnej mieszkańców i turystów w Szczecinie oraz próba identyfikacji relacji przestrzeni rekreacji i przestrzeni turystycznej.

Szczecin jest miastem rozległym przestrzennie (ok. 301 km²), w którym obszary zielone o zróżnicowanych cechach zajmują 17,54\% powierzchni miasta, a wraz z terenami wodnymi $(23,68 \%)$ i użytkami rolnymi stanowią 60,81\% całkowitej powierzchni (Raport 2017). Tak duży udział terenów wodnych i zielonych w sposób istotny wpływa na charakter miasta oraz kształtuje korzystne warunki do uprawiania rekreacji. Korzystanie z warunków środowiskowych ułatwia stale rozwijająca się infrastruktura (przystanie wodne, ką- pieliska, polany leśne, ścieżki dydaktyczne, szlaki, drogi rowerowe), a ponadto $\mathrm{w}$ mieście funkcjonuje wiele obiektów umożliwiających realizację różnych form aktywności rekreacyjnej. Dominują wśród nich obiekty i urządzenia służące do uprawiania rekreacji fizycznej, takie jak: stadiony (12), boiska (231), pływalnie kryte (8), przystanie wodne (12), korty tenisowe (7) czy siłownie na wolnym powietrzu (14). Opierając się na zapleczu technicznym, funkcjonują $\mathrm{w}$ mieście podmioty umożliwiające realizację różnorodnych pasji, takie jak: kluby sportowe (273), siłownie, szkoły tańca, kluby fitness, domy kultury i inne. W zakresie infrastruktury wykorzystywanej do rekreacji kulturalno-rozrywkowej należy wymienić: filharmonię (w której w 2016 r. zorganizowano 436 wydarzeń), kina (5), muzea (7) i teatry (5). Ta syntetyczna prezentacja potencjalnych miejsc rekreacji w Szczecinie nie stanowi ich szczegółowego przeglądu, ma na celu jedynie sygnalne wskazanie miejsc i możliwych typów rekreacji.

Wyniki badań przeprowadzonych wśród mieszkańców Szczecina wskazują, że największą ilością czasu wolnego w dni powszednie (1-2 godzin) dysponują ludzie młodzi (ponad połowa osób w wieku 18-30 lat), a większość osób w wieku 41-50 lat deklaruje czas wolny jedynie w weekendy. Do form aktywności najczęściej wybieranych przez szczecinian w czasie wolnym należą: rekreacja na świeżym powietrzu (75\% kobiet i 55\% mężczyzn), gry logiczne (szachy, karty, gry planszowe) i sporty wodne (ok. 30\% osób), ponadto mężczyźni chętnie wybierają sporty siłowe (35\%), a kobiety fitness (39\%). Najmniej popularne są sporty ekstremalne i jazda konna. Zdecydowana większość badanych (77\%) samodzielnie organizuje sobie rekreację w czasie wolnym, pozostała część zaś korzysta z zajęć zorganizowanych.

Deklarowana przez mieszkańców aktywność rekreacyjna na wolnym powietrzu to przede wszystkim spacery (prawie 50\% wskazało taką aktywność z częstotliwością kilka razy w tygodniu), jazda na rowerze (13\% respondentów), praca w ogródku (6\%) i nordic walking $(3 \%)$. Kilka razy w miesiącu respondenci decydują się na bieganie (17\%) i gry zespołowe $(13 \%)$, kilka razy do roku zaś na korzystanie z kąpielisk $(43 \%)$, lodowisk (34\%), polan rekreacyjnych (32\%) czy udział w imprezach masowych (31\%). Miejscami najczęściej wybieranymi do uprawiania aktywności na wolnym powietrzu są: Park Kasprowicza (48\%) i Jasne Błonia (39\%) oraz Wały Chrobrego (35\%), Puszcza Bukowa (24\%) i Las Arkoński (18\%).

Prawie $2 / 3$ badanych deklarowało korzystanie $\mathrm{z}$ oferty obiektów sportowo-rekreacyjnych (ok. 5\% więcej mężczyzn niż kobiet) - najczęściej osoby w wieku 25-30 lat (ponad 80\%). Do obiektów wybieranych kilka razy w miesiącu, które wymieniło ponad 10\% respondentów, zalicza się: fitness kluby (20\%), baseny $(18 \%)$, sauny $(14 \%)$ i siłownie $(14 \%)$. Najrzadziej ko- 
rzystano (z częstotliwością kilka razy w roku przez mniej niż 10\% badanych) z kortów tenisowych czy squasha. Najczęściej wybieraną przez respondentów formą rekreacji biernej było wyjście do kina (77\% deklarowało je kilka razy w roku) oraz spotkania ze znajomymi (40\% respondentów korzystało z tej możliwości kilka razy w miesiącu). Na co dzień respondenci oglądają głównie telewizję (45,4\%). Ponad 12\% badanych grało codziennie $\mathrm{w}$ gry komputerowe i robiło zakupy.

W 2015 r. Szczecin odwiedziło prawie 390000 turystów, z czego około 34\% stanowili turyści zagraniczni, przede wszystkim z Niemiec (ok. 43\%) i Skandynawii (Danii, Szwecji i Norwegii). Wyniki przeprowadzonych badań wskazały, że główną aktywnością turystów podczas pobytu w Szczecinie było uczestnictwo w imprezach okolicznościowych (82\%) i kulturalnych $(52 \%)^{2}$. Ponad połowa respondentów zwiedzała miasto, około $48 \%$ odpoczywało na obszarach zielonych, a blisko $45 \%$ robiło zakupy. Turyści zagraniczni rzadziej niż turyści krajowi brali udział w imprezach kulturalnych czy relaksowali się na obszarach zielonych i nadwodnych, częściej zaś zwiedzali miasto i uczestniczyli w imprezach okolicznościowych. Z infrastruktury rekreacyjno-sportowej miasta skorzystało 2³ badanych. Największą popularnością wśród turystów cieszyły się miejskie szlaki turystyczne (38\%), ścieżki rowerowe (33\%) oraz spa \& wellness $(32 \%)$. W ramach rekreacji kulturalno-rozrywkowej wybierali przede wszystkim puby i dyskoteki (55\%), kina (50\%), muzea (33\%) oraz filharmonię i teatr (27\%). Główne obszary aktywności turystów w Szczecinie to Wały Chrobrego (72\%), park Kasprowicza wraz z Jasnymi Błoniami i Ogrodem Różanym (65\%), Zamek Książąt Pomorskich (63\%) oraz promenada nad Odrą (62\%).

Zestawienie form aktywności turystów odwiedzających Szczecin z zachowaniami mieszkańców w czasie wolnym pozwala zauważyć dużą zbieżność, zarówno $\mathrm{w}$ formach aktywności, jak i obszarach ich uprawiania. Nie wydaje się możliwe nie tylko rozgraniczenie przestrzeni turystycznej i przestrzeni rekreacji, ale nawet jednoznaczne wyodrębnienie przestrzeni turystycznej czy przestrzeni rekreacji w mieście. Nawet obiekty noclegowe, których przeznaczenie jest typowo turystyczne, najczęściej dysponują ofertą, z której na co dzień (a nie incydentalnie) korzystają mieszkańcy (gastronomia, imprezy okolicznościowe, szkolenia, kursy, spa \& wellness i in.), z kolei miejsca pracy mieszkańców mają infrastrukturę pozwalającą na realizację aktywności rekreacyjnej.

Ilustruje to dobrze nakładanie się funkcji w przestrzeni, szczególnie na obszarach o wysokim stopniu zagospodarowania i zaludnienia, jakimi są obszary miejskie. Sam fakt pełnienia przez tę samą część prze- strzeni różnych funkcji nie jest ani nowy, ani niezwykły, ale postępująca interferencja coraz większej liczby funkcji powoduje, że trudno jest w sposób jednoznaczny określić dominujący charakter przestrzeni, wynikający z pełnionej przez nią funkcji. Ocena intensywności czy natężenia zjawisk w przestrzeni coraz rzadziej ma prosty wymiar ilościowy, implikując trudności w satysfakcjonującym określeniu jej tożsamości (obecnej i pożądanej), co ma istotne znaczenie np. w procesie planowania danej przestrzeni czy zarządzania nią.

\section{PODSUMOWANIE}

Czas wolny i fakt jego posiadania wpływają na poczucie dobrostanu psychicznego jednostki i jakość życia społeczeństw. W analizie ekonomicznej ważnym problemem jest ocena roli czasu wolnego w budżecie gospodarstwa domowego i czasu społecznego, w rozwoju społeczno-gospodarczym, kreowaniu kapitału ludzkiego oraz dobrobycie ekonomicznym i jakości życia (CZAJA 2011, s. 234). Zasoby czasu wolnego i sposoby jego wykorzystania stają się kategorią diagnostyczną procesów rozwoju społeczno-gospodarczego (BOMBOL 2008). O jakości życia mogą świadczyć liczba i rodzaje usług, z jakich korzysta się w czasie wolnym. Można przyjąć, że uczestnictwo w formach aktywności sektora czasu wolnego jest składową oraz wyznacznikiem zadowolenia psychicznego i poczucia wysokiej jakości życia. Wymagająca praca tworzy zapotrzebowanie na aktywność w czasie wolnym, biegunowo inną od aktywności typowej dla tej pracy (BOMBOL 2005, s. 27).

Powoduje to określone konsekwencje w decyzjach dotyczących zachowań turystycznych i rekreacyjnych. Zwiększenie liczby wyjazdów w połączeniu ze skróceniem długości ich trwania przyczyniło się do wzrostu liczby odwiedzin na obszarach zurbanizowanych, które dysponują zróżnicowaną ofertą skierowaną w równej mierze do mieszkańców i turystów. Jednocześnie wraz z postępującą kompresją czasu wolnego aktywność turystów na odwiedzanych obszarach staje się podobna do aktywności wolnoczasowej mieszkańców, co powoduje jej realizację w tym samym otoczeniu. Dodatkowo turyści dążą do poznania codziennego życia miasta (turystyka poza szlakiem), a mieszkańcy zachowują się jak turyści we własnym mieście, odkrywając je na nowo. W przestrzeni miasta postępuje interferencja przestrzeni rekreacji i przestrzeni turystycznej, uniemożliwiająca ich rozdzielenie, ale nadal pozwalająca na wyodrębnienie pewnych podprzestrzeni o wyższej intensywności zachowań turystycznych lub rekreacyjnych. 


\section{PRZYPISY}

1 Celem tego opracowania nie jest definiowanie pojęcia „przestrzeń rekreacji”, ani też systematyzacja przestrzeni rekreacji. Szeroka dyskusja nad zakresem pojęciowym, cecha$\mathrm{mi}$, funkcjami i systematyzacją przestrzeni rekreacji oraz jej relacjami z przestrzenią turystyki i przestrzenią czasu wolnego odbyła się podczas konferencji naukowej „Przestrzenie rekreacji - granice i konteksty", na Wydziale Nauk Geograficznych (Instytut Geografii Miast i Turyzmu) Uniwersytetu Łódzkiego (21-22.11.2017). Wyniki dyskusji prowadzonej na różnych płaszczyznach powinny przyczynić się do sformułowania docelowej definicji przestrzeni rekreacji oraz ściślejszego określenia relacji pomiędzy przestrzenią czasu wolnego, rekreacji i turystyki. Przyjęta na potrzeby artykułu definicja przestrzeni rekreacji (i jej podziały) ma charakter ramowy i służy przede wszystkim precyzyjnej prezentacji wyników badań.

2 Mógł mieć na to wpływ termin przeprowadzenia badań.

\section{BIBLIOGRAFIA}

AUSTIN D.R., LEE Y., 2013, Inclusive and special recreation opportunities for diverse populations to flourish, Sagamore Publishing LLC, s. 396.

BELLEZZA S., PAHARIA N., KeINAN A., 2017, Conspicuous consumption of time: When business and lack of leisure time become a status symbol, ,JJournal of Consumer Research", 44 (1), s. 118-138.

BOMBOL M., 2005, Ekonomiczny wymiar czasu wolnego, Szkoła Główna Handlowa w Warszawie, Warszawa.

BOMBOL M., 2008, Czas wolny jako kategoria diagnostyczna procesów rozwoju społeczno-gospodarczego, Szkoła Główna Handlowa w Warszawie, Warszawa.

BUTLER R., 2006, Volatile demand for tourism? - We can only market efficiently to what we know, rather than to what we imagine, [w:] P. Keller, T. Bieger (eds.), Marketing efficciency in tourism. Coping with volatile demand, Erich Schmidt Verlag, Berlin, s. $13-22$.

CZAJA S., 2011, Czas w ekonomii, Wyd. Uniwersytetu Ekonomicznego we Wrocławiu, Wrocław.

DĄBROWSKI A. (red.), 2006, Zarys teorii rekreacji ruchowej, Wyd. AlmaMer WSE, AWF Warszawa, Warszawa.

DRZEWIECKI M., 1992, Wiejska przestrzeń rekreacyjna, Instytut Turystyki, Warszawa.

GOŁEMBSKI G., NIEZGODA A., 2012, The role of time in the global tourism market - A demand perspective, [w:] M. Kasimoglu (ed.), Visions for global tourism industry, InTech, Rijeka, s. 167-178.

GULAM A., 2016, Recreation - need and importance in modern society, „International Journal of Physiology, Nutrition and Physical Education", 1 (2), s. 157-160.

HAWORTH J.T., 1997, Work, leisure and well-being, Routledge, London, http://www.questia.com/PM.qst?a=o\&d=103046280.

HURD A.R., ANDERSON D.M., 2011, The park and recreation professional's

handbook, http://www.humankinetics.com/excer pts/excerpts/definitions-of-leisure-playand-recreation.

JUNG B., 2011, W kierunku nowej ekonomii czasu wolnego, [w:] R. Winiarski (red.), Rekreacja i czas wolny. Studia humanistyczne, Oficyna Wydawnicza Łośgraf, Warszawa, s. 160-174.
KACHNIEWSKA M., NAWROCKA E., NieZgoda A., PAWLICZ A., 2012, Rynek turystyczny, Wolters Kluwer, Warszawa.

KOWALCZYK A., 2000, Geografia turyzmu, Wyd. Naukowe PWN, Warszawa, s. 287.

KOWALCZYK A., 2014, Fenomenologia przestrzeni turystycznej, „Tourism/Turyzm”, 24/1, s. 915.

KRAUS R., PETERSON J.A., MARTIN W.D., 1985, Recreation and leisure: The changing scene, Jones and Burtlett Publishers, s. 309.

KRAUS R., 1971, Recreation and leisure in modern society, AppletonCentury-Croft, New York, s. 312.

LISZEWSKI S., 1995, Przestrzeń turystyczna, „Turyzm”, 5, 2, s. 87-103.

LISZEWSKI S., 2013, Treści, formy, przestrzenie i klasyfikacje turystyki (artykut dyskusyjny), [w:] R. Wiluś, J. Wojciechowska (red.), Nowe-stare formy turystyki w przestrzeni, ser. „Warsztaty z Geografii Turyzmu", 3, Wyd. Uniwersytetu Łódzkiego, Łódź, s. 9-20.

MEERAS L., 2010, Leisure and recreation, University of Tartu, College Department of Tourism, Pärnu, s. 50.

MEYER B. (red.), 2015, Obstuga uczestników turystyki i rekreacji. Wybrane aspekty, Wyd. Difin S.A., Warszawa, s. 356.

MYŚLIWSKA K., 2011, Socjologia czasu wolnego, [w:] R. Winiarski (red.), Rekreacja i czas wolny. Studia humanistyczne, Oficyna Wydawnicza Łośgraf, Warszawa, s. 134-159.

NiEZGODA A., 2014, Czas wolny a zmiany na rynku turystycznym, [w:] B. Krakowiak, J. Latosińska (red.), Przeszłość, teraźniejszość i przyszłość turystyki, ser. „Warsztaty z Geografii Turyzmu”, 5, Wyd. Uniwersytetu Łódzkiego, Łódź, s. 101-113.

NiEZGODA A., 2017, Leisure and tourism - relationship and changes, „Folia Turistica”, 44.

Raport o stanie miasta Szczecin 2016, http://bip.um.szczecin.pl/ chater_11808.asp?soid=E1F8717034EF4BC4A54CDD4C7 3258EB4.

ReICH F., PeChlaner H., HOelzl B., 2006, Price satisfaction in the hotel industry, [w:] P. Keller, T. Bieger (red.), Marketing efficciency in tourism. Coping with volatile demand, Erich Schmidt Verlag, Berlin, s. 107-116.

REID D.G., Fuller A.M., HAYWOOD K.M., BRYDEN J., 1993, The integration of tourism, culture and recreation in rural Ontario, Queen's Printer, Toronto.

TANAŚ S., 2008, Miejsce cmentarzy w turystyce kulturowej - wokót problemu badawczego, „Turystyka Kulturowa”, 2, s. 4-16.

TOCZEK-WERNER S., 2007, Podstawy rekreacji i turystyki, Wyd. Akademii Wychowania Fizycznego, Wrocław.

TOFFLER A., 2001, Trzecia fala, Państwowy Instytut Wydawniczy, Warszawa.

VEAL A.J., 1992, Definitions of leisure and recreation, "Australian Journal of Leisure and Recreation", 2 (4), s. 44-48, 52; Republished by School of Leisure, Sport and Tourism, University of Technology, Sydney, as Working Paper No. 4, accessed at: www.business.uts.edu.au/lst/research.

Whitrow G.J., 2004, Czas w dziejach, Wyd. Prószyński i S-ka, 296 ss.

WIĘCKOWSKI M., 2014, Przestrzeń turystyczna - próba nowego spojrzenia, „Tourism/Turyzm”, 24/1, s. 17-24.

WŁODARCZYK B., 2014, Przestrzeń w turystyce, turystyka w przestrzeni - o potrzebie podziałów i klasyfikacji, ",Tourism/ Turyzm”, $24 / 1$, s. 25-34.

Artykuł wpłyną: 19 grudnia $2017 \mathrm{r}$. Zaakceptowano do druku: 26 lutego $2018 \mathrm{r}$. 